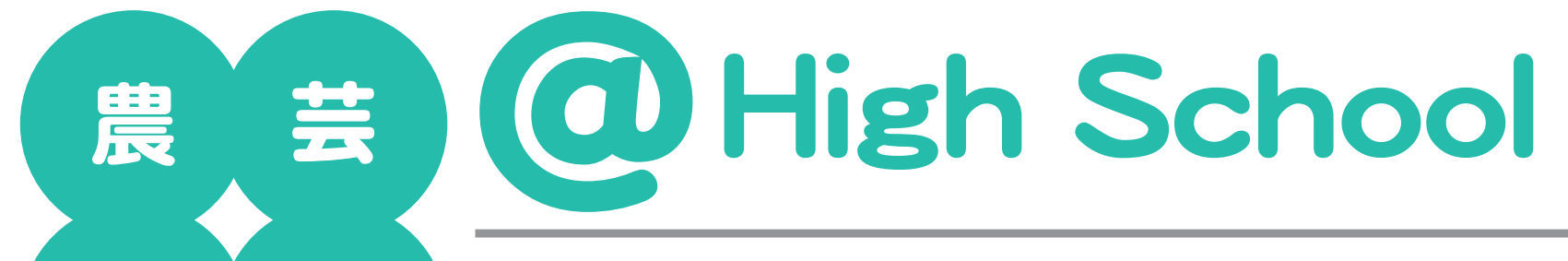

岐阜県立岐阜農林高等学校

河合香帆，三浦功太郎（顧問：安藤耕作）

本研究は, 日本農芸化学会 2015 年度（平成 27 年度）大会 （開催地：岡山大学）「ジュニア農芸化学会2015」で発表さ れたものである. 発表者は, 地元特産の原木栽培干し椎茸に よる Ca 吸収促進に着目した. 干し椎苜の成分分析によりビ タミン $\mathrm{D}_{2}$ 含量が高いことを確認するとともに，それをマウ スに与えて骨形成実験を行った. その結果, ジャコとともに 干し椎苜を与えたマウスで骨形成促進効果が見いだされた. 原木栽培干し椎茸とさまざまな食材とを組み合わせて食べる ことにより骨形成に効果があるという, 栄養学, 食育の観点 からたいへん興味深い研究であった.

\section{本研究の目的, 方法および結果}

\section{【背景と目的】}

超高龄化社会に突入しつつある現代の日本において， 高齢者が生活の質（QOL）を維持しつつ，自立した生 活を送ることは非常に大事である，高齢者の健康寿命を 維持, 延長する観点から近年特に注目されているのがロ コモティブシンドローム（運動器症候群； locomotive syndrome）である(1, 2). ロコモティブシンドローム（以 下ロコモ）は，骨，関節，筋肉の機能障害により運動機 能が低下した状態である。ロコモを誘発する疾患として 骨粗鬆症, 変形関節症, サルコペニアなどがあるが, こ れらはいずれも骨と筋肉に深くかかわるものである.

ビタミンDの主な作用は, カルシウム吸収を促進する ことで骨を丈夫にすることととらえられがちであったが， 近年筋肉の形成を促進する作用をもつことが明らかとな り，サルコペニアのように筋肉量が減少する疾患を予防 する観点からもビタミン Dの重要性はますます高まっ ている。このように，ビタミン Dはこれまでの骨の強化 という観点を越え, 運動機能全体の維持, 向上という観
点からも積極的に摂取すべき重要な栄養素である.

干し椎咠は, ビタミン $\mathrm{D}_{2}$ を豊富に含む食品である. 本研究では, 岐皁県産干し椎茸のロコモ予防への効果を 検討するため, ビ夕ミン $\mathrm{D}_{2}$ 含有量を測定するとともに, 骨形成への影響をさまざまな条件下で動物を使って調べ た，その結果，岐阜県産干し椎茸「しいたけブラザー ズ」が高いビタミン $\mathrm{D}_{2}$ 含有量を示すこと, カルシウム を豊富に含む食品（ジャコ）と一緒に食べさせると骨形 成が促進したこと,さらにその作用は日光浴により増強 されたことが示された。

実験 1 : 干し椎茸のビタミン $\mathrm{D}_{2}$ 含量分析

岐阜県産「しいたけブラザーズ」に含まれるビタミン $\mathrm{D}_{2}$ 含量を解析した。この干し椎茸は, 原木栽培により 得られた椎咠を天日干しにて製造したものである（図 1). ビタミン $\mathrm{D}_{2}$ 量は Nield-Russel-Zimmerli法 ${ }^{(3,4)}$ にて

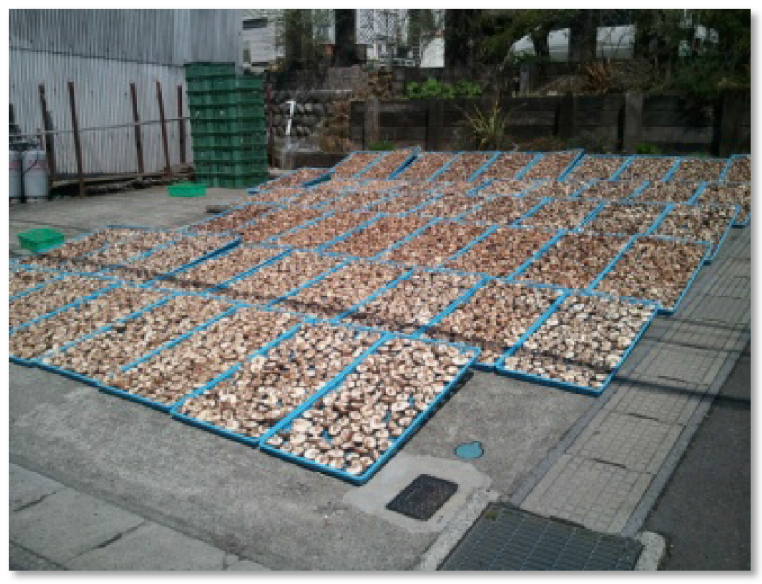

図1・しいたけブラザーズの天日干し 
測定した。また，比較のため，ほかの国産原木干し椎 茸，中国産菌床干し椎茸も測定した。可食部 $100 \mathrm{~g}$ 当た りのビタミン $\mathrm{D}_{2}$ 量を比較したところ，しいたけブラ ザーズの含量は $86 \mu \mathrm{g} / 100 \mathrm{~g}$ 可食部であった。一方，ほ かの 2 検体のビタミン $\mathrm{D}_{2}$ 含量は $16 \mu \mathrm{g} / 100 \mathrm{~g}$ 可食部（国 産原木栽培干し椎咠), $8.7 \mu \mathrm{g} / 100 \mathrm{~g}$ 可食部 (中国産菌床 栽培干し椎茸）であり，しいたけブラザーズには約5〜 10 倍量のビタミン $\mathrm{D}_{2}$ が含まれていることがわかった。

椎茸に含まれるプロビタミン $\mathrm{D}_{2}$ (エルゴステロール) は紫外線を受けて, ステロイド環が開裂し, ビタミン $\mathrm{D}_{2}$ (エルゴカルシフェロール) に変換される。 このこ とから, 干し椎茸中のビタミン $\mathrm{D}_{2}$ 量は紫外線の照射状 況（天日干しされた季節や時間）により変動しうるこ と, 各製品のビタミン $\mathrm{D}_{2}$ 含量にはロット差が存在する であろうことが考えられる。したがって，各製品のビ夕 ミン $\mathrm{D}_{2}$ 量を比較するときは慎重にならねばならないが, 一般的な干し椎咠 $(16 \mu \mathrm{g} / 100 \mathrm{~g} \text { 可食部 })^{(5)}$ に比べても, しいたけブラザーズのビタミン $\mathrm{D}_{2}$ 含量は高いと言える.

\section{実験 $2 ：$ 䬣の違いによるCa吸収への効果}

干し椎茸「しいたけブラザーズ」に含まれるビタミン $\mathrm{D}_{2}$ がCa吸収に及ぼす効果を明らかにするため，マウス の成長および骨形成への影響を検討した。マウスは 3 週 齡のオス ddYを用いた。マウスを3匹ずつ5群に分け, それぞれの群に異なる種類の慨（表1）を与え，体重の 変化を経時的に測定し，給餌開始後31日目に摘出した 大腿骨の長さと重量を測定した。また，2群について は，日光浴の効果を調べるために，快晴日に10分間の 日光浴を行った（図2）。

干し椎咠とジャコを食べたマウスの体重は, ペレット のみを餌としたマウスに比べ，大きい傾向があった (1-2群 vs. 3-5群; 図3)。ただ，ジャコ+椎茸（5群） の体重は, 椎茸のみ (3群), あるいはジャコのみ $(4$ 群）の体重とはほとんど差は認められなかった。

表 1 - 䭒の成分

\begin{tabular}{cccc}
\hline 群 & 基本餌成分 & 添加成分 & 日光浴の有無 \\
\hline 1 群 & ペレット & $\times$ & $\times$ \\
2 群 & ペレット & $\times$ & $\bigcirc$ \\
3 群 & ペレット & 干し椎茸 & $\times$ \\
4 群 & ペレット & ジャコ & $\times$ \\
5 群 & ペレット & 干し椎茸, ジャコ & $\times$ \\
\hline
\end{tabular}

ペレットは一般動物飼料を用いた。 ジャコは Ca供給源として添加 した. ジャコ, 干し椎茸の添加量を算出するに当たって，それぞ れビタミン D およびCa量が摂取基準の上限を超えない最大量とな るようにした（65 kgのヒトが摂取可能な上限量を算出し，マウス の平均体重に対して比例計算で算出した. 算出に用いた数值の由 来は「日本人の食事摂取基準 2015 年度版」)
干し椎茸とジャコの骨形成への効果は, 大腿骨の重量 (図4), 長さ（図5）で比較検討した。5群（ジャコ+椎 茸）の骨重量は明らかに大きいことがわかった（図5). このことは，優れた原木栽培技術により生産され，天日 干しされた「しいたけブラザーズ」に含まれる豊富なビ

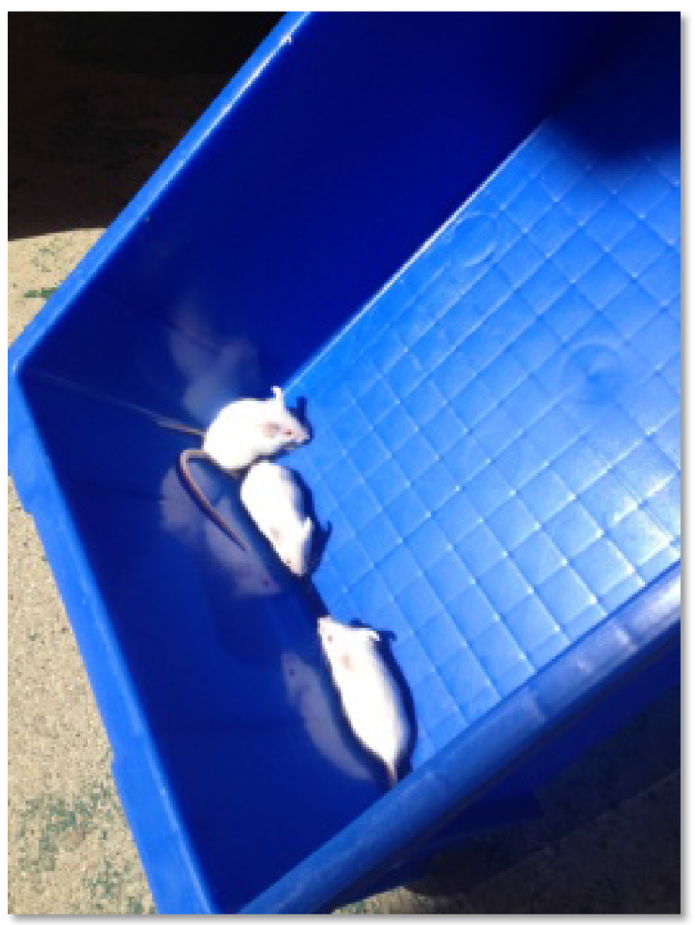

図2・マウスの日光浴

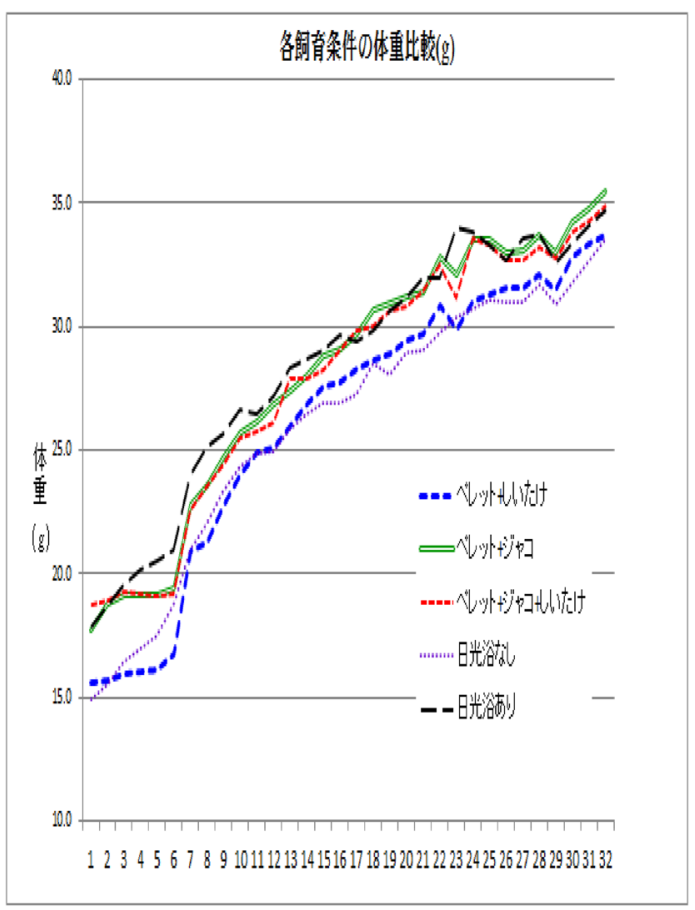

図3・干し椎茸とジャコの体重変化に与える影響 


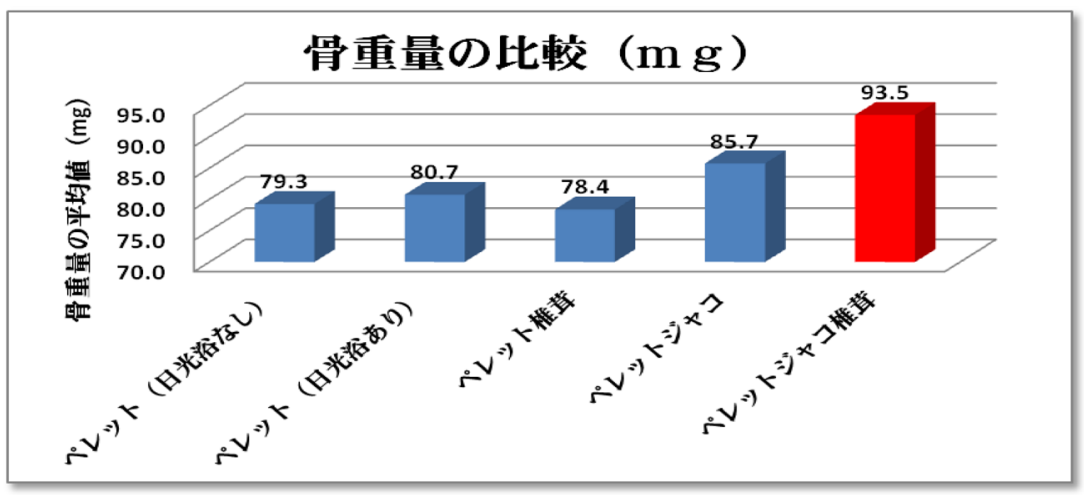

図 4ロ干し椎茸, ジャコを与えたマウス大腿 骨の重量

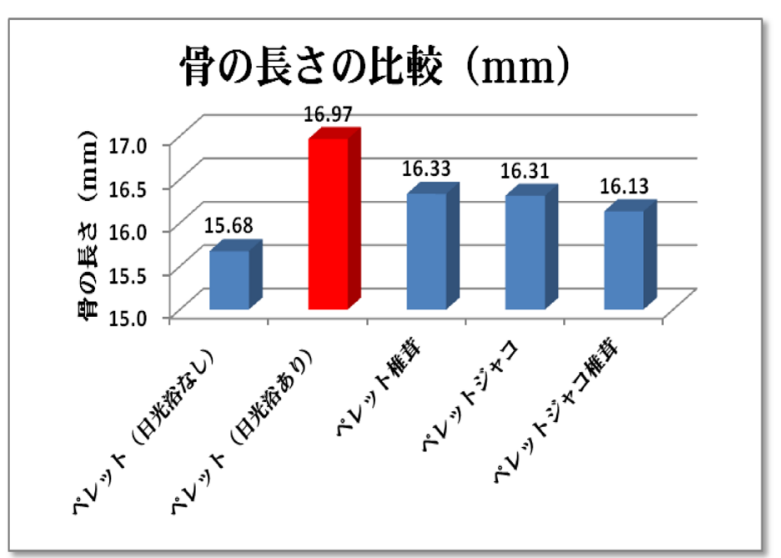

図 5 ロ 干し椎茸, ジャコを与えたマウス大腿骨の長さ

タミン $\mathrm{D}_{2}$ がCa吸収を促進し，骨形成に貢献したのでは ないかと考えられる. 動物において, ビタミン $\mathrm{D}_{2}$ は動 物体内で合成されるビタミン $\mathrm{D}_{3}$ （コレカルシフェロー ル）と同様の活性を有することが知られているが，本実 験においてもビ夕ミン $\mathrm{D}_{2}$ が $\mathrm{Ca}$ 吸収に有効であるという 結果が得られた。

日光浴の効果についても, 興味深い知見が得られた。 日光浴を行ったマウスでは日光浴をしていないマウスに 比べ，大腿骨の長さが平均 $1 \mathrm{~mm}$ 以上長くなった（1群 vs. 2 群; 図5).しかし, 骨重量に大きな差がなかった ため (図4), 結果的に単位骨長当たりの骨重量では日 光浴を行ったマウスのほうが低くなる傾向が見いだすこ とができたこのことは，日光浴を行ったマウスでは骨 は伸びたが骨密度は低い骨になったことを示唆してい る.このことは, 干し椎茸十ジャコを与えたマウスでは 丈夫な骨ができたこととは興味深い対比をなしている. 一つの仮説として，干し椎茸に含まれるビタミン $\mathrm{D}_{2}$ は 骨重量を増やす方向に作用するのに対して，日光浴で生 じるビタミン $\mathrm{D}_{3}$ は骨長を延ばす方向に作用することが
考えられる.ビタミン $\mathrm{D}_{2}$ と $\mathrm{D}_{3}$ にこのような明確な作用 の違いがあるという知見はまだないと思われるが，ほか の可能性（摂取タンパク質の量と質の違い, 摂取 $\mathrm{Ca}$ 量 の違い，運動状況の違いなど）とともに，検証できれば たいへん抄もしろいと考えられる。 また，別の解釈とし て，マウスにとって日光浴がストレスとして作用した可 能性が考えられる．夜行性のマウスにとって日光浴は一 般的な生活環境にはない状況であり，このことでストレ スがかかり骨は伸びたが，骨密度が低い状態を招いたの ではないかと考えられる。この考えについてもまだ仮説 の域をでるものではないが，骨の長さと重量に別々に作 用することがあるとしたら興味深い現象であるので今後 の検証が待たれる。

今後は，干し椎咠を食したマウスの血中 $\mathrm{Ca}$ 濃度を測 定する，葉酸を多く含む食材の効果を調べるなどを行っ ていきたい.

\section{文献}

1）公益社団法人日本整形外科学会：新概念「ロコモティブ シンドローム (運動器症候群)」(http://www.joa.or.jp/ $\mathrm{jp} / \mathrm{public} / \mathrm{locomo} /$ )

2）厚生労働省 :「健康づくりのための身体活動基準 2013」お よび「健康づくりのための身体活動指針（アクティブガ イド)」について (http://www.mhlw.go.jp/stf/houdou/ 2r9852000002xple.html)

3) C. H. Nield, W. C. Russel \& A. Zimmerli: J. Biol. Chem., 136, 73 (1940).

4) 京都大学農芸化学教室編: 新改版農芸化学実験書（増補） 第2巻 (第 26 版), 産業図書(株), 1976.

5）文部科学省科学技術・学術審議会・資源調査分科会：五 訂日本食品標準成分表, 2005.

（文責「化学と生物」編集委員）

Copyright (C) 2016 公益社団法人日本農芸化学会 DOI: 10.1271/kagakutoseibutsu.54.141 